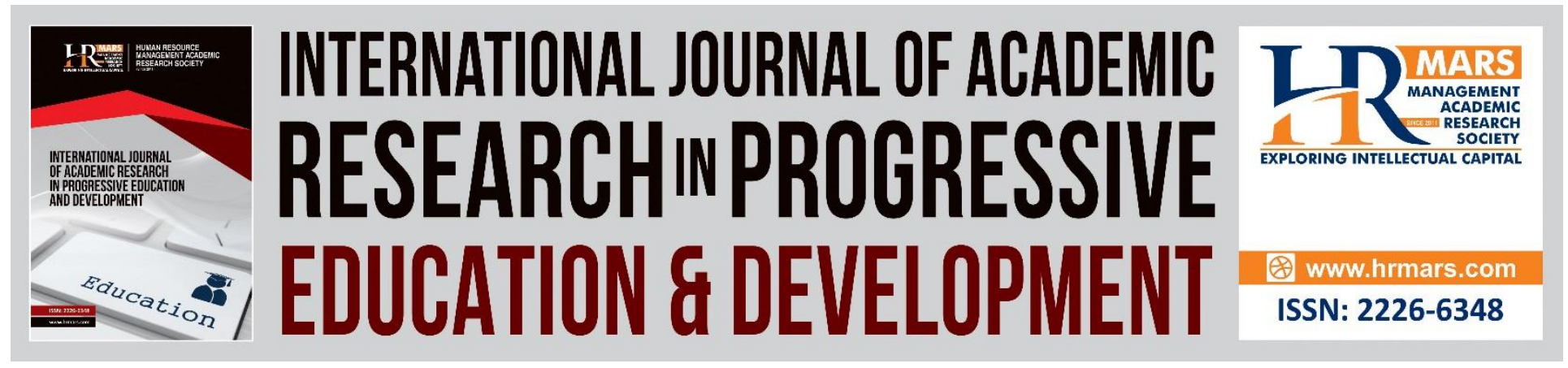

\title{
A Critical Analysis of Malay Symbolism in Datuk Syed Ahmad Jamal Artwork: Gunung Ledang, 1978
}

Nurkhazilah Idris and Liza Marziana Muhammad Noh

To Link this Article: http://dx.doi.org/10.6007/IJARPED/v7-i4/4839

DOI: $10.6007 /$ IJARPED/v7-i4/4839

Received: 13 Aug 2018, Revised: 17 October 2018, Accepted: 09 Nov 2018

Published Online: 17 Nov 2018

In-Text Citation: (Idris \& Noh, 2018)

To Cite this Article: Idris, N., \& Noh, L. M. M. (2018). A Critical Analysis of Malay Symbolism in Datuk Syed Ahmad Jamal Artwork: Gunung Ledang, 1978. International Journal of Academic Research in Progressive Education and Development, 7(4), 95-108.

Copyright: (C) 2018 The Author(s)

Published by Human Resource Management Academic Research Society (www.hrmars.com)

This article is published under the Creative Commons Attribution (CC BY 4.0) license. Anyone may reproduce, distribute, translate and create derivative works of this article (for both commercial and non-commercial purposes), subject to full attribution to the original publication and authors. The full terms of this license may be seen

at: http://creativecommons.org/licences/by/4.0/legalcode

\section{Vol. 7, No. 4, 2018, Pg. 95 - 108}

http://hrmars.com/index.php/pages/detail/IJARPED

JOURNAL HOMEPAGE

Full Terms \& Conditions of access and use can be found at http://hrmars.com/index.php/pages/detail/publication-ethics 


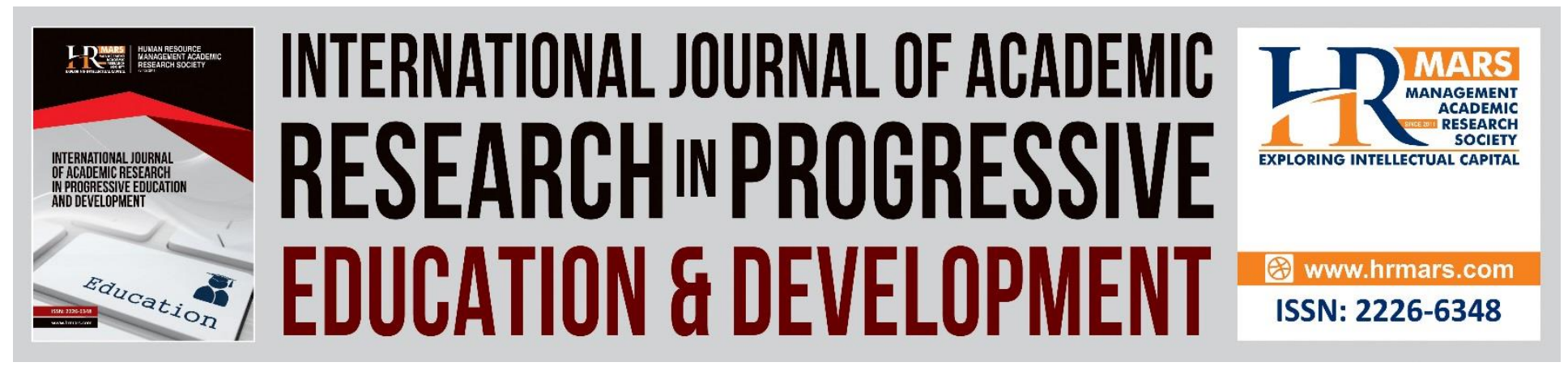

\title{
A Critical Analysis of Malay Symbolism in Datuk Syed Ahmad Jamal Artwork: Gunung Ledang, 1978
}

\author{
Nurkhazilah Idris and Dr. Liza Marziana Muhammad Noh \\ Faculty of Art and Design, Universiti Teknologi Mara, Alor Gajah Campus, Melaka
}

\begin{abstract}
This critical analysis is about the Malay symbolism in found in Datuk Syed Ahmad Jamal artwork named Gunung Ledang that produced in 1978. This research is looking at the Malay symbols which the beauty concept of art that Datuk Syed Ahmad Jamal was renowned with. The reason of bring up an artwork of Datuk Syed Ahmad Jamal as medium analysis to this topic writing because among the group of painter in Malaysia, he had considered as a lead of abstract painter in year 1960an until 1970, which is in lot of his art work had using the symbolism elements, point to metaphor approach and intrinsic meaning (Syed Ahmad Jamal Sempena Malam Anugerah Seni Negara, 1995). The theoretical framework of this analysis is by Edmund Feldman (1993) which is four step structure of criticism consisting of description, analysis, interpretation and judgment. It is hoped that this research would reach out to the public and further provide a bridge linking the public's understanding with matters related to the visual arts, enlightening the Malay symbolism along with greater appreciation on Malay element of meanings behind an artist's effort and thus encourage public appreciation and understanding on the concept of beauty within the Malay cultural tradition context on visual arts. Findings from this research are hoped to assist further research or study on the definitive elements of Malaysian heritage. Artwork Gunung Ledang produced by Datuk Syed Ahmad Jamal possesses high analytical and intrinsic meanings that landmarked a significant contribution to the Malaysian Art history.
\end{abstract}

Keywords: Malay, Symbolism, Datuk Syed Ahmad Jamal, Artwork.

\section{Introduction}

This critical analysis is about the Malay symbolism found in Datuk Syed Ahmad Jamal artwork named Gunung Ledang that produced in 1978. This research is looking at the Malay symbols which the beauty concept of art that Datuk Syed Ahmad Jamal was renowned with. The reason of bring up an artwork of Datuk Syed Ahmad Jamal as medium analysis to this topic writing because among the group of painter in Malaysia, he had considered as a lead of abstract painter in year 1960an until 1970, which is in lot of his artwork had using the symbolism elements, point to metaphor approach and intrinsic meaning (Syed Ahmad Jamal Sempena Malam Anugerah Seni Negara, 1995). 
The selected artwork Gunung Ledang, 1978 by Datuk Syed Ahmad Jamal as a media to this research will coincide this critical analysis which is about Malay symbolism. This is because, in book, Modern Artists of Malaysia, it was stated that, Datuk Syed Ahmad Jamal's most recent endeavours indicate new preoccupations with the questions of cultural identity. His emergence as a serious writer on traditional Malay forms has resulted to expose a publication of the book, Rupa dan Jiwa which attempts to expose an indigenous aesthetic in Malay art form (Redza Piyadasa, 1983). Furthermore, in Datuk Syed Ahmad Jamal work of art also refers to themes from traditional legends and Malay literature as reflected in 'Gunung Ledang' (Redza Piyadasa and Sabapathy, 1983).

Refer to Siti Zainon Ismail (1985),

'Simbol boleh dikatakan sebagai pemberian semula jadi terhadap perkembangan sesuatu imej. Ini bererti dengan kesedaran tujuan dan kegunaan, bentuk simbolik mempunyai erti tersendiri yang mewakili pencipta seni. Dalam perkembangan seni rupa, unsur begini tidak dapat diabaikan. la merupakan satu fungsi dari imej itu sendiri. Dalam kegiatan seni rupa ketiga-tiga bentuk iaitu sumber, lambang dan tanda merupakan ciri penting bagi seniman dalam mewujudkan imejnya untuk sesebuah karya seni. Kewujudan ini berdasarkan kemampuan mencipta, mengolah seluruh imaginasi dan pengalaman emosi serta intelektual'.

(Siti Zainon Ismail, 1985)

According to the book Rupa dan Jiwa, written by Datuk Syed Ahmad Jamal, also talked about the aesthetic and appreciation toward the beauty of Malay arts. He stated that,

'Karya seni itu juga dianggap sebagai objek yang 'ideal' pada perasaan pemerhati. Seni membawa seseorang itu dari alam biasa ke alam estetika. Pengalaman itu menyerap dalam pengamatan estetika'.

(Syed Ahmad Jamal, 1992)

Therefore, it shows that the writer had applied the aesthetic philosophy to talk about Malay art form. Justified, it is seen that the selected artwork, Gunung Ledang, 1978 by Datuk Syed Ahmad Jamal was suitably and will completely answer the problem statement of this analysis.

Looking toward trough Gunung Ledang, Datuk Syed Ahamd Jamal was applied the valuable design of symbolism on this artwork. The factor influenced him applied this elements because he had exposed to the flow of Abstract Expressionism while Datuk Syed Ahmad Jamal study at England in year 1950, which is feeling at around the world. Abstract Expressionism in visual arts was one of flow which can be defined as the freedom to changes the form and colour for express the mood or emotion. It also explore deeply in worlds of sold and the result had created the powerful and darkness that hunched it.

The characteristic of brushwork was compact and expressive. So it become as medium for reveals an emotion to audients. The effect of that, Datuk Syed Ahmad Jamal had produced an 
INTERNATIONAL JOURNAL OF ACADEMIC RESEARCH IN PROGRESSIVE EDUCATION AND DEVELOPMENT

Vol. 7, No. 4, 2018, E-ISSN: 2226-6348 @ 2018 HRMARS

artworks using the elements of symbolism until to right now. Furthermore, after 40 years, artwork named Gunung Ledang still can be stand as an artwork which is very valuable and able to draw the amazement among young artists. The recipe that Datuk Syed Ahmad Jamal used to produce this valuable artwork is absolutely was the element of symbolism.

Findings from this research are hoped to assist further research or study on the definitive elements of Malay heritage. Artwork Gunung Ledang, 1978 produced by Datuk Syed Ahmad Jamal possesses high analytical and intrinsic meanings that land-marked a significant contribution to the Malaysian Art history. Datuk Syed Ahmad Jamal has single handedly through his works intellectualize and articulated the Malaysian society in a different light and perspective by empowering them with significant meanings found in his artworks. Therefore, the analysis of Datuk Syed Ahmad Jamal's artwork title Gunung Ledang would be heavily based upon the understanding surmised in the former paragraph.

The theoretical framework of this analysis is by Edmund Feldman (1993) which is four step structure of criticism consisting of description, analysis, interpretation and judgment. This research can be defined the meaning behind the Malay symbol on his artwork. These research also can make this analysis to be as medium for encourage public appreciate and understanding the elements of Malay symbolism in visual arts. In the same time to bring up the environment of produce an artwork with have the element of analytic meaning and intrinsic of Malay cultural tradition.

\section{Problem Statement}

According to Siti Zainon Ismail on her writing in book named Getaran Jalur and Warna say,

'Alangkah baiknya jika unsur-unsur simbolik ini benar-benar dapat difahami oleh generasi sekarang, tidak sekadar meniru dari apa yang pernah dihasilkan oleh orang yang terdahulu'.

(Siti Zainon Ismail, 1985)

From, the author's observation on public in Malaysia especially young generation, they doesn't understand the element of symbolism in artwork which is apply to bring something an analytical and intrinsic meaning. Furthermore, among the art student's element of Malay symbolism also had less apply in their artwork. Base on that, by doing this critical analysis of the Malay symbolism in Datuk Syed Ahmad Jamal artwork title Gunung Ledang, 1978 can solve this problem.

\section{Objectives}

The objectives of this critical analysis in Datuk Syed Ahmad Jamal artwork named Gunung Ledang that produced in 1978 are to assist further research or study on the definitive elements of Malay symbolism. Focus of this study also to identify the elements of symbolism and intrinsic interpretation on the meaning behind the Datuk Syed Ahmad Jamal artwork that land-marked a significant contribution to the Malaysian Art history. 
INTERNATIONAL JOURNAL OF ACADEMIC RESEARCH IN PROGRESSIVE EDUCATION AND DEVELOPMENT

Vol. 7, No. 4, 2018, E-ISSN: 2226-6348 @ 2018 HRMARS

\section{Methodology}

The theoretical framework of this analysis is by Edmund Feldman (1993) which is four step structure of criticism consisting of description, analysis, interpretation and judgment.

Table 1. Method of Art Criticism - The Critical Process by Edmund Feldman

\begin{tabular}{|c|c|c|}
\hline No. & $\begin{array}{c}\text { The Critical Process by } \\
\text { Edmund Feldman }\end{array}$ & \multicolumn{1}{c|}{ The Critical Process } \\
\hline 1. & $\begin{array}{c}\text { Description } \\
\text { Naming and describing the facts }\end{array}$ & $\begin{array}{l}\text { Naming what an observer sees is part of the } \\
\text { overall process of description. }\end{array}$ \\
\hline 2. & $\begin{array}{c}\text { Analysis } \\
\text { Analyzing the facts }\end{array}$ & $\begin{array}{l}\text { Dealing with visual evidence. It is an } \\
\text { advanced type of description. }\end{array}$ \\
\hline 3. & $\begin{array}{c}\text { Interpretation } \\
\text { Interpreting the evidence }\end{array}$ & $\begin{array}{l}\text { The crucial third stage of art criticism: this is } \\
\text { the point at which our search for meaning } \\
\text { reaches a climax. }\end{array}$ \\
\hline 4. & $\begin{array}{l}\text { Judgment } \\
\text { Judging the works of art }\end{array}$ & $\begin{array}{l}\text { Final stage of evaluation of criticism is the } \\
\text { evaluation of whole works of art. This sort } \\
\text { of judging may seem presumptuous or } \\
\text { perhaps it is downright foolish. }\end{array}$ \\
\hline
\end{tabular}




\section{Data Analyzing}

The Critical Process in Gunung Ledang (1978)

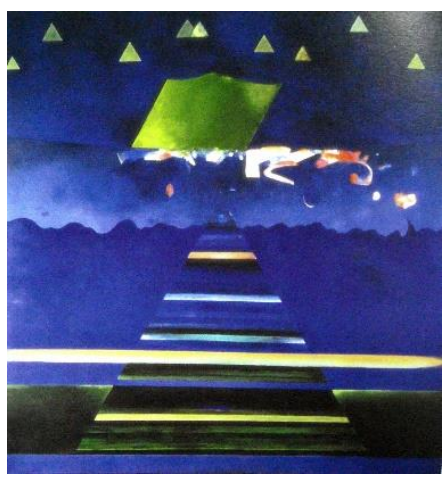

\section{Description}

Figure 1. Gunung Ledang (1978)

Gunung Ledang was produced by Datuk Syed Ahmad Jamal in year 1978 . The size was $213 \mathrm{x}$ $203 \mathrm{~cm}$ and the medium that artist used is acrylic and canvas. This artwork was permanent collection of Singapore Art Museum.

\section{Analysis}

Datuk Syed Ahmad Jamal in his mythical Gunung Ledang, 1978, owes much to the ideas of Kandinsky and Malevich (Mohamed Ali Abdul Rahman, Modern Malaysia Art : Manifestation of Malay Form and Content, 2008). The selected color that applied was a cool color such as blue and green which is dominantly in this artwork. This colour is based on natural materials that was reveals the panorama at Gunung Ledang. Another colour that also applied in this artwork was a black $\mathrm{n}$ white. There are also the several of warm color that artist used in order to make this work more esthetic. It was a red and yellow color. Furthermore, Datuk Syed Ahmad Jamal using the flat space to imagery his ideal in this painting. Because of that, this art works automatically create the illusion of abstract expression towards the image of Gunung Ledang.

This artwork applied a geometric shape such triangle and horizontal line which is clearly influence by Abstract Expressionist. The horizontal lines had been arranged from base to the top and to form a big triangle. This big triangle was dominated these painting and it becomes as the focus point. From analysis on this artwork, also find that the symbolism form of triangular which is divided into seven layers of horizontal bands and which reaches upwards from the ground towards the sky. The image of this triangle shapes and the prepetition of horizontal line is as below:

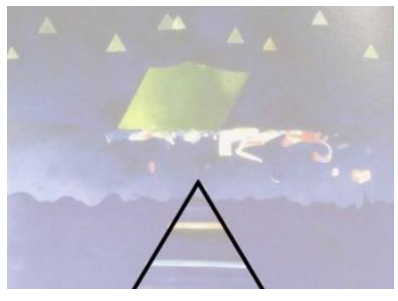




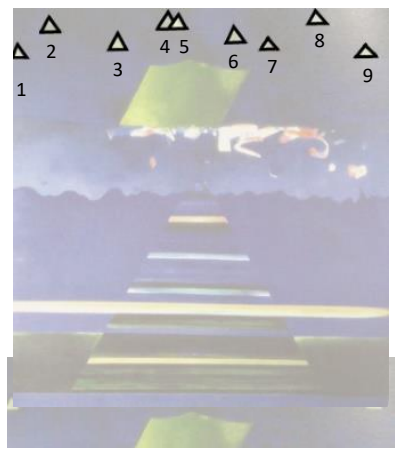

Figure 3. The founding of nine triangle shape

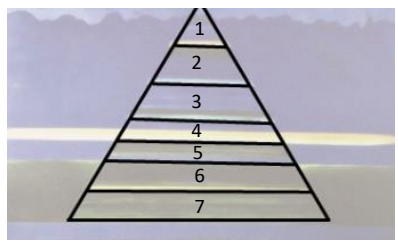

Figure 4. The founding of seven layer horizontal lines

\section{Interpretation}

Based from ancient history, points to the mountain being the site of rich gold deposits, luring traders of Malacca called it 'KimSua' meaning the 'Golden Mountain'. Another source said that the Javanese during the period of the Majapahit empires named the mountain 'Gunong Ledang', which means 'mount from afar'.

Wikipedia Free Encyclopedia on Gunung Ledang

The analysis towards this artworks had look that land of the magical mountain, where the palace of the princess of Ledang Mount was believed to be located is symbolized by a large triangle. Furthermore this art work also base on the folk story which is 'Puteri Gunung Ledang' that famously around Malay Culture. An analytical of this legendary story was the mystical behind the narrative which is told the power of loved that Puteri Gunung Ledang to Hang Tuah.

Besides that, the theme of this painting also base on a Malaysian Airliness System (M.A.S) air crash that happened near the village of Tanjung Kupang in state of Johor. Datuk Syed Ahmad Jamal creates an iridescent image in which pain, violence, gore and horror have been expunged and sublimated. This air crash happened in year 1978 and the flight was from Penang to Kuala Lumpur. According to T.K.Sabapathy say in his writing stated that, 'There were no survivors and the cause of the crash has never been completely and satisfactorily established. Among those who died was Datuk Ali Haji Ahmad, who was the Minister of Agriculture at the same time, and a close friend of Syed Ahmad Jamal. The event shocked the entire nation (Syed Ahmad Jamal, A Historical Overview 1954 - 1994, 1994).' 
INTERNATIONAL JOURNAL OF ACADEMIC RESEARCH IN PROGRESSIVE EDUCATION AND DEVELOPMENT

Vol. 7, No. 4, 2018, E-ISSN: 2226-6348 @ 2018 HRMARS

This art painting also applied the esthetic of Islamic Art through the geometric shape which is triangle. It pictures a style which is an identity that depiction the personality and national value, society, culture and religion. The interesting in this art work is the thinking of development which is begin from the below to the top that to interpreted the symbolism of the spirit mount.

In this artwork, Datuk Syed Ahmad Jamal also express the geometric shape which is triangle to be used as symbolize an energy and prosperity the mountain of Gunung Ledang that also knows as Mount Ophir which is in Johor, Malaysia. There are two size of triangle. One was paint in a big size and dominated in this artwork. Whenever there are also nine small triangles in that compose in the top of this painting. Mohamed Ali Abdul Rahman in book Modern Malaysian Art: Manifestation of Malay Form and Content state that:

'... Sed Ahmad Jamal in his mythical Gunung Ledang, 1978, owes much to the ideas of Kandinsky and Malevich. The triangles in this painting are derived from symbolical South East Asian Tumpul or Pucuk Rebung (Bamboo Shoots) that always appear in the decorative design of Malay cloth such as songket and Batik'.

(Rahman, 2008)

The manifestation through this artwork is to bring the element of culture heritage base on triangle form which is clearly dominant applied. Refer to Figure 5. is a triangle shape bring the various meaning such as Pucuk Rebung (Bamboo Shoots) and Tumpal that symbolize of fertility. Furthermore the motive of triangles is symbolism as 'pohon hayat' and 'bunga semangat' represent the manifestation of universe. Base on this element it can be as medium to bring up the traditional Malay heritage to the world. In the same time, it can become an education medium to young generation to know the traditional culture. According to Sabapathy, this work, like nearly all of Syed Ahmad Jamal's work consciously symbolic. The triangular motif is again an archetypal motif. The cosmopolitan character of Syed Ahmad Jamal's thinking and outlook has ensured that the search for cultural roots need not become bogged down by sentimentalism and indulgence. Herein, lies his strength as a modern artist (Sabapaty \& Piyadasa, 1983).

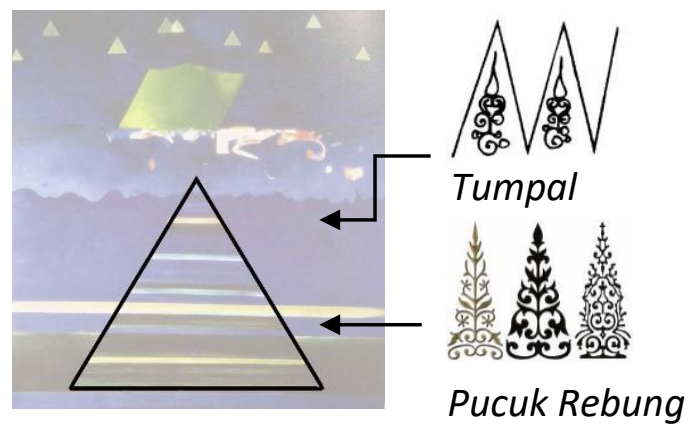

Figure 5. The founding of symbolic meaning behind a triangle shape 
Vol. 7, No. 4, 2018, E-ISSN: 2226-6348 @ 2018 HRMARS

The magical mountain, where the palace of the palace of the princess of Ledang Mount was believed to be located is symbolized by a large triangle which is divided into large triangle which reaches upwards from the ground towards the sky. Besides that, the large triangle that metaphor as Gunung Ledang also symbol of the universe is known to many world cultures; it has deep roots in Southeast Asia, appearing at a number of historical periods and in widely belief systems (Sabapathy, 1994).

Furthermore, from analysis on this work, also find that the symbolism shape of triangular which is divided into seven layers of horizontal bands and which reaches upwards from the ground towards the sky was brought the meaning as seven level of sky (tujuh petala langit) that was a essence in Islam religion.

The triangle also consists of seven layers that corresponding to the seven heavenly realms in the Malay account of creation. An interestingly, the seventh realm is to be the abode of the Orang Syurga, or those in a state of bliss of heaven. From interpretation on this artwork also reveals, the symbolism shape of triangular which is divided into layers of horizontal bands and which reaches upwards from the ground toward the sky also bring up the meaning of relationship not only among human but with universe and God.

Superimposed on the triangle, towards its base and spanning the breadth of the picture surface, is a belt of searing light; it is a symbolic representation the impossible conditions that Princess of Gunung Ledang set for Sultan Melaka, for her hand in marriage. The impossible condition was a golden bridge for Princess of Gunung Ledang to walk to Melaka from the mountain and a silver bridge for her to return from Malacca to the mountain. There are another five conditions that Puteri Gunung Ledang had request to Sultan Melaka as a gift for their marriage. The conditions were seven jars of virgin's tears, seven bowls of betel nut juice, seven trays filled with hearts of germs, seven tray filed with hearts of mosquitoes and a bowl of the blood of the Sultan's young son. All this had combined with intrinsic and analytical approach trough the repetition horizontal line in image of the large triangles.

Looking through the nine small triangles that compose in the top of this painting was represent the influence elements of heaven. With this element it had change the physical form of stars to become the small triangles. The nine small triangles had capable of unending variation towards the composition in dynamic quality even as it is intrinsically stable, whether it equilateral or isosceles, it is symmetrical. Therefore, the nine triangles in this painting was brought the ideological exudes of harmony and authority.

The zone of atmospheric light is the only area in the composition in which states of flux are discernible, fragmented, bent and twisted shapes painted in red, the fiery shards that remain of the crash, are the vestigial representations of the horrifying end; they are the only, direct or overt references to the material outcome of event. Above this is the heavenly sphere; a patch of green signifies the burial ground in which the remains of those who perished are interred. 
Vol. 7, No. 4, 2018, E-ISSN: 2226-6348 @ 2018 HRMARS

Looking the colours that Datuk Syed Ahmad Jamal had applied in Gunung Ledang as the color based on natural materials which is blue and green. The reason of using this color is because it shows the face of universe. The green color is describes the meaning of base part that represent an earth and the top part which is blue color was the sky. The green and blue color that dominated in this art work was the right choice to showing the element of an earthly and paradise. Besides that, blues and greens dominate the colour spectrum; pigments have been brushed and laid, methodically and evenly; gestural and kinetic inflections have been suppressed in order to avoid sensuous indulgence and optical distraction. Base on interpretation that have been done also find that the blue color was ironic to the element of truth and harmony. While the green color was symbolize the meaning of spacious and also have positive element.

Whenever, the red colour was represent the elements blood of victim that died in air crash tragedy. From interpretation also find that the red color was symbols of the relation that Datuk Syed Ahmad Jamal with his close friend, Datuk Ali Haji Ahmad who died in air crash. Through this colour also symbolize the sad emotion and tears to the people in that accident. The yellow colour in this painting was symbol to the understanding and high sight. The chosen of this color was very suitable with the symbolize meaning of nine small triangular shapes that compose in the top of this art work. In aspect of yellow gold colour that Datuk Syed Ahmad Jamal applied in this art work was to symbolize to the elements of dignity, pride and peacefulness.

Looking to the white colour that paint in the middle of this artwork was symbolize the air crash splinter and the die spirit. Hear, Datuk Syed Ahmad Jamal giving the significance of all the die spirit had go to the sky which is compose upon of the large triangle and in the same time symbolize that spirits was to be placed at heaven. Furthermore, from analysis in this artwork also reveals that Datuk Syed Ahmad Jamal also used the black colour and applied it in several layers of horizontal bands in rows to become a large triangle. The meaning of this colour was represent the negative element which is symbolize the vanished and the lost thing in someone life.

\section{Judgment}

The manifestation through this art work is to bring the element of culture heritage base on triangle shape which is clearly dominant applied. The triangle shapes bring the various meaning such as Pucuk Rebung (Bamboo Shoots) that symbolism of fertility. Furthermore the motive of triangles is symbolism as 'pohon hayat' and 'bunga semangat' represent the manifestation of universe. Base on this element it can be as medium to bring up the traditional Malay heritage to the world. In the same time, it can become an education medium to young generation to know the traditional culture. According to Sabapathy, this work, like nearly all of Datuk Syed Ahmad Jamal's work consciously symbolic. The triangular motif is again an archetypal motif. The cosmopolitan character of Datuk yed Ahmad Jamal's thinking and outlook has ensured that the search for cultural roots need not become bogged down by sentimentalism and indulgence. Herein, lies his strength as a modern artist (Sabapaty \& Piyadasa, 1983).

\section{Finding and Discussion}

The critical analysis towards the elements of symbolism in Datuk Syed Ahmad Jamal artwork named Gunung Ledang, 1978 was reveals an intellectualizing, analytical and intrinsic 
INTERNATIONAL JOURNAL OF ACADEMIC RESEARCH IN PROGRESSIVE EDUCATION AND DEVELOPMENT

Vol. 7, No. 4, 2018, E-ISSN: 2226-6348 @ 2018 HRMARS

meaning in order to become as significance theme in his work of art. In this artwork, Datuk Syed Ahmad Jamal also reveals the different application on way of perceptive and perception ideological thinking in creating his art works that made it such high valuable in expressing the symbolism elemets. The findings of this study can be summarized as follows:

Table 2. Finding and Discussion

\begin{tabular}{|c|c|c|}
\hline No. & Finding & The Symbolism Meaning \\
\hline 1. & $\begin{array}{l}\text { Artist Style and } \\
\text { Concept }\end{array}$ & $\begin{array}{l}\text { Geometric shape which is triangle was become as trademarks and } \\
\text { identity of Datuk Syed Ahmad Jamal in producing an artworks. }\end{array}$ \\
\hline 2. & $\begin{array}{l}\text { Spirit Mountain of } \\
\text { Gunung Ledang }\end{array}$ & $\begin{array}{l}\text { A triangle shape are symbolize an energy and prosperity } \\
\text { mountain of Gunung Ledang that also knows as Mount Ophir } \\
\text { which is in Johor. }\end{array}$ \\
\hline 3. & $\begin{array}{l}\text { Folk Story and } \\
\text { Legendary }\end{array}$ & $\begin{array}{l}\text { The magical mountain, where the palace of princess Ledang } \\
\text { Mount who was believed to be located at Gunung Ledang } \\
\text { which is symbolized by a large triangle. } \\
\text { - Base on the folk story which is 'Puteri Gunung Ledang' that } \\
\text { famously around Malay Culture. An analytical of this } \\
\text { legendary story was the mystical behind the narrative which } \\
\text { is told the power of loved that Puteri Gunung Ledang to } \\
\text { Hang Tuah. }\end{array}$ \\
\hline 4. & $\begin{array}{l}\text { Malay Cultural } \\
\text { Heritage }\end{array}$ & $\begin{array}{l}\text { - Bring the element of Malay cultural heritage base on triangle } \\
\text { shape which is clearly dominant applied. } \\
\text { - A triangle shape bring the various meaning such as Pucuk } \\
\text { Rebung (Bamboo Shoots) and Tumpal that symbolize of } \\
\text { fertility. The motive of triangles is symbolism as 'pohon hayat' } \\
\text { and 'bunga semangat' represent the manifestation of } \\
\text { universe. }\end{array}$ \\
\hline 5. & $\begin{array}{l}\text { Aircraft Crash } \\
\text { Tragedy }\end{array}$ & $\begin{array}{l}\text { - Symbolize a Malaysian Airliness System (M.A.S) air crash that } \\
\text { happened near the village of Tanjung Kupang in state of Johor. } \\
\text { The red colour was represent the elements blood of victim } \\
\text { that died in air crash tragedy. } \\
\text { - Datuk Syed Ahmad Jamal creates an iridescent image in which } \\
\text { pain, violence, gore and horror have been expunged and }\end{array}$ \\
\hline
\end{tabular}




\begin{tabular}{|c|c|c|}
\hline & & $\begin{array}{l}\text { sublimated. This air crash happened in year } 1978 \text { and the } \\
\text { flight was from Penang to Kuala Lumpur. Among those who } \\
\text { died was Datuk Ali Haji Ahmad, who was the Minister of } \\
\text { Agriculture at the same time, and a close friend of Datuk Syed } \\
\text { Ahmad Jamal. }\end{array}$ \\
\hline 6. & $\begin{array}{l}\text { Elements of Islamic } \\
\text { Art }\end{array}$ & $\begin{array}{l}\text { - Applied the esthetic of Islamic Art through the geometric } \\
\text { shape which is triangle. It pictures a style which is an identity } \\
\text { that depiction the personality and national value, society, } \\
\text { culture and religion. } \\
\text { - Seven layers of horizontal bands and which reaches upwards } \\
\text { from the ground towards the sky was brought the meaning as } \\
\text { seven level of sky (tujuh petala langit) that was a essence in } \\
\text { Islam religion. } \\
\text { - The symbolism shape of triangular which is divided into layers } \\
\text { of horizontal bands and which reaches upwards from the } \\
\text { ground toward the sky also bring up the meaning of } \\
\text { relationship not only among human but with universe and } \\
\text { God. } \\
\text { The repetition and stylization shape of triangle and horizontal } \\
\text { line was the element in Eastern Art. }\end{array}$ \\
\hline 7. & Positive Elements & $\begin{array}{l}\text { - The green color is describes the meaning of base part that } \\
\text { represent an earth symbolize the meaning of spacious and } \\
\text { also have positive element. } \\
\text { - The yellow gold colour that Datuk Syed Ahmad Jamal applied } \\
\text { in this art work was to symbolize to the elements of dignity, } \\
\text { pride and peacefulness. }\end{array}$ \\
\hline 8. & Negative Elements & $\begin{array}{l}\text { The black colour that applied in several layers of horizontal bands } \\
\text { in rows to become a large triangle which represent the meaning of } \\
\text { the negative element that symbolize the vanished and the lost } \\
\text { thing in someone life. }\end{array}$ \\
\hline
\end{tabular}

\section{Conclusion}

In conclusion, the all element of symbolism had been apply in Datuk Syed Ahmad Jamal artwork title Gunung Ledang, 1978 with analytical and intrinsic meaning. From this context, Datuk Syed Ahmad Jamal want to bring the society to think with intellectualizing in way to translation the significant meaning in his artwork. Besides that, from this research also find that 


\section{INTERNATIONAL JOURNAL OF ACADEMIC RESEARCH IN PROGRESSIVE EDUCATION AND DEVELOPMENT}

Vol. 7, No. 4, 2018, E-ISSN: 2226-6348 @ 2018 HRMARS

in Datuk Syed Ahmad Jamal artwork had apply many elements of Malay symbolism which is included from the side of shape, colour, composition, space and line. This element had been present with harmonies arrangement and made it such high valuable. So, unsurprised if this artwork had become as permanent collection of Singapore Art Museum, in order as references to young artist and society although in local or over sea. Furthermore, the application of the element of Malay symbolism, made the Datuk Syed Ahmad Jamal work of art had bring up not only the Malay cultural tradition but also the values or religion position in Islam. It clearly, with using the geometric shape which is non naturalism or realism form that emphasized through repetition and stylization that was the element in Eastern Art. What the expectations trough this artwork Gunung Ledang, 1978 by painter Datuk Syed Ahmad Jamal must to take as an example to young artists. It because, in way of application the Malay symbolism, that artist used as style and concept in creating the artworks.

\section{Corresponding Author}

Nurkhazilah Binti Idris

Email: ilaidris@ymail.com

Faculty of Art and Design

Universiti Teknologi Mara

Alor Gajah Campus

Jalan Lendu, 7800

Melaka

\section{References}

Edmund, B. F. (1993). Practikal Art Criticism. New Jersey: Prentice Hall.

Mohamed, A. A. R. (2008). Modern Malaysian Art : Manifestaton of Malay Form and Content. Shah Alam: University Publication Centre (UPENA).

Redza, P., \& Sabapathy T. K. (1983). Modern Artists of Malaysia. Kuala Lumpur: Dewan Bahasa dan Pustaka.

Sabapathy, T. K. (1994). Syed Ahmad Jamal : A Historical Overview 1954-1994. Kuala Lumpur: Nanyang Gallery of Art Sdn. Bhd.

Sabapathy, T. K. (1994). Vision and Idea : ReLooking Modern Malaysian Art. Kuala Lumpur: National Art Gallery.

Sharifah, F. Z. (1984). Simbolisme Dalam Kesenian Islam. Kuala Lumpur: Balai seni lukis Negara.

Syed, A. J. (1987). Seni Lukis Malaysia 57-87. Kuala Lumpur: Balai Seni Lukis Negara.

Syed, A. J. (1992). Rupa dan Jiwa. Kuala Lumpur: Dewan Bahasa dan Pustaka. 


\section{INTERNATIONAL JOURNAL OF ACADEMIC RESEARCH IN PROGRESSIVE EDUCATION AND}

DEVELOPMENT

Vol. 7, No. 4, 2018, E-ISSN: 2226-6348 @ 2018 HRMARS

Siti, Z. I. (1985). Getaran Jalur dan Warna. Petaling Jaya: Fajar Bakti Sdn. Bhd. Kuala Lumpur: Balai Seni Lukis Negara. 